\title{
Biosynthesis of butyrate from methanol and carbon monoxide by recombinant Acetobacterium woodii
}

\author{
Nilanjan Pal Chowdhury ${ }^{1} \cdot$ Dennis Litty ${ }^{1} \cdot$ Volker Müller $^{1}$ (1)
}

Received: 17 September 2021 / Revised: 21 December 2021 / Accepted: 11 January 2022 / Published online: 18 February 2022

(c) The Author(s) 2022

\begin{abstract}
Methanol is one of the most widely produced organic substrates from syngas and can serve as a bio-feedstock to cultivate acetogenic bacteria which allows a major contribution to reducing greenhouse gas. Acetobacterium woodii is one of the very few acetogens that can utilize methanol to produce acetate as sole product. Since A. woodii is genetically tractable, it is an interesting candidate to introduce recombinant pathways for production of bio-commodities from methanol. In this study, we introduced the butyrate production operon from a related acetogen, Eubacterium callanderi KIST612, into A. woodii and show a stable production of butyrate from methanol. This study also reveals how butyrate production by recombinant A. woodii strains can be enhanced with addition of electrons in the form of carbon monoxide. Our results not only show a stable expression system of non-native enzymes in A. woodii but also increase in the product spectrum of A. woodii to compounds with higher economic value.
\end{abstract}

Keywords Acetogen $\cdot$ Butyrate $\cdot$ Bioengineering $\cdot$ Wood-Ljungdahl pathway $\cdot$ Acetogenesis $\cdot$ Carbon cycling

\section{Introduction}

In times of global warming, there is an increasing need to reduce $\mathrm{CO}_{2}$ emissions into the atmosphere. Therefore, petroleum-based technologies for the production of added-value compounds need to be replaced by sustainable biotechnological approaches. Various bacteria and archaea are known to convert $\mathrm{CO}_{2}$ but strictly anaerobic, acetogenic bacteria have gained much interest in recent times for they grow in the dark in the absence of oxygen, are easy to cultivate, and are metabolically very diverse (Drake 1994; Müller 2003; Drake et al. 2008). They can grow lithotrophically on $\mathrm{H}_{2}+\mathrm{CO}_{2}$, some also on syngas $\left(\mathrm{H}_{2}+\mathrm{CO}_{2}+\mathrm{CO}\right)$, on $\mathrm{C} 1$ compounds such as formate or methanol but also organotrophically on various sugars, carbonic acids, aldehyde, primary, and secondary alcohols (Drake et al. 1997; Schuchmann and Müller 2016). Many of these metabolic pathways go along with the fixation of $\mathrm{CO}_{2}$. For example, acetogenesis from methanol according to:

Volker Müller

vmueller@bio.uni-frankfurt.de

1 Department of Molecular Microbiology \& Bioenergetics, Institute of Molecular Biosciences, Johann Wolfgang Goethe University, Max-von-Laue Str. 9, 60438 Frankfurt, Germany
$4 \mathrm{CH}_{3} \mathrm{OH}+2 \mathrm{CO}_{2} \leftrightarrow 3 \mathrm{CH}_{3} \mathrm{COOH}+\mathrm{H}_{2} \mathrm{O}$

requires half a mol of $\mathrm{CO}_{2}$ per mol of methanol converted.

Methanol is a promising feedstock for acetogens and it can be produced from syngas chemically and then used to feed acetogens without the problems inherent to gas fermentation (Cotton et al. 2019; Satanowski und BarEven 2020; Kremp und Müller 2021). Butyrate is such an added value compound that is the starter molecule for butanol production, a biofuel with a much higher energy density than ethanol and some acetogens like Clostridium carboxidivorans, Clostridium drakei (Liou et al. 2005), Eubacterium callanderi KIST612 (Chang et al. 1997; Litty and Müller 2021), and few intestinal acetogens like Butyvibrio crossotus and Eubacterium rectale (van den Abbeele et al. 2013) have been shown before to produce butyrate naturally. Butyrate was also produced from syngas in co-culture of Clostridium kluyveri and Clostridium autoethanogenum (Diender et al. 2016). Here, we have metabolically engineered one of the most robust and wellstudied acetogens, Acetobacterium woodii, as a new production platform for butyrate formation from fructose or methanol. 


\section{Results}

\section{Generation of recombinant A. woodii}

To generate a recombinant $A$. woodii strain able to produce butyrate, we chose to clone the butyrate production genes from E. callanderi KIST612, an acetogen known to produce butyrate naturally. E. callanderi KIST612 harbors the genes encoding thiolase (thlA, ELI_0537), 3-hydroxybutyryl-CoA dehydrogenase ( $h b d$, ELI_0538), crotonase (crt, ELI_0539), and the electron bifurcating butyryl-CoA dehydrogenase complex (bcd/etfAB, ELI_0540-0542). While the genes of the butyrate pathway are clustered in a single gene cluster, the phosphobutyryl transferase ( $p t b$, ELI_0834) is encoded elsewhere in the genome. Unfortunately, there is no annotated butyrate kinase gene in the genome. First, we cloned the genes $t h l A, h b d$, crt, and $b c d /$ etf $A B$ of the butyrate cluster in plasmid pMTL84211 (Purdy et al. 2002; Heap et al. 2007) under the control of pta-ack (phosphotransacetylase-acetate kinase) promoter from Clostridium ljungdahlii giving rise to the plasmid pMTL84211pAck_NP_But6. A second plasmid was also created which contained the $P t b$ gene along with its $137 \mathrm{bp}$

A

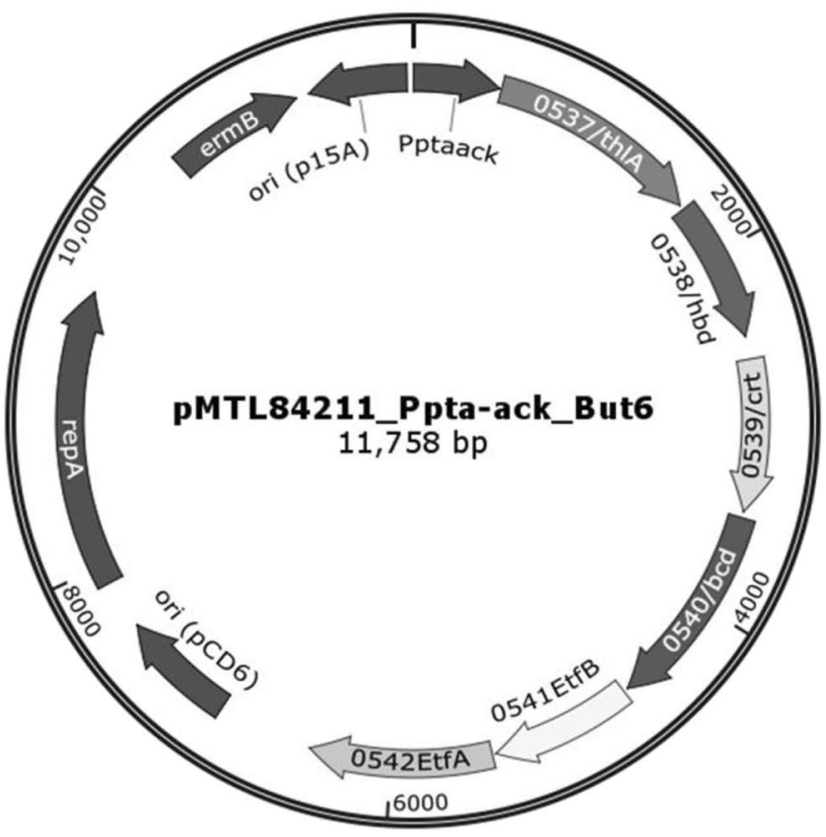

Fig. 1 Physical map of plasmids containing genes of recombinant butyrate pathway. The constructed expression plasmid pMTL84211Ack_NP_But6 (A) and plasmid pMTL84211Ack_NP_But7 (B) harboring six and seven genes, respectively, of butyrate synthetic pathway used to transform WT A. woodii. Key: thlA, thiolase; $h b d$, hydroxybutyryl-CoA dehydrogenase; crt, crotonase; bcd/etfBA, bifurcating butyryl-CoA dehydrogenase complex; ptb, phosphotransbu- upstream region forming the plasmid pMTL84211pAck NP_But7 (Fig. 1).

The plasmids were transferred into A. woodii and the recombinants grew well on fructose with doubling times of $9.8 \mathrm{~h}$ (Aw_But6 strain) and $9 \mathrm{~h}$ (Aw_But7 strain) to similar final optical densities (Fig. 2). Each of these strains produced acetate, as expected, but Aw_But6 and Aw_But7 also produced butyrate. In Aw_But6, the yield was low but clearly above the control and the yield was increased by $400 \%$ up to a concentration of $1.5 \mathrm{mM}$ in Aw_But7 (Fig. 2). In total, the carbon recovery was $78-83 \%$, not accounting for $\mathrm{CO}_{2}$.

The increased production of butyrate in Aw_But7 argued for the $p t b$ gene being transcribed in addition resulting in an active phosphobutyryl transferase leading to the production of butyryl phosphate which is further dephosphorylated to butyrate. Indeed, this was observed; genes encoding butyrate production like thlA and $h b d$ were expressed in A. woodii during growth on fructose in Aw_But6 and Aw_But7 strain and in addition, $p t b$ was also transcribed in Aw_But7 strain (Fig. 3). Apparently, co-transcription of $p t b$ led to higher butyrate yields. Although butyrate kinases are not annotated in the genomes of $A$. woodii or $E$. callanderi, cell-free extract of fructose-grown cells of $A$. woodii and E. callanderi catalyzed butyrate kinase activity with 0.43 and 0.57

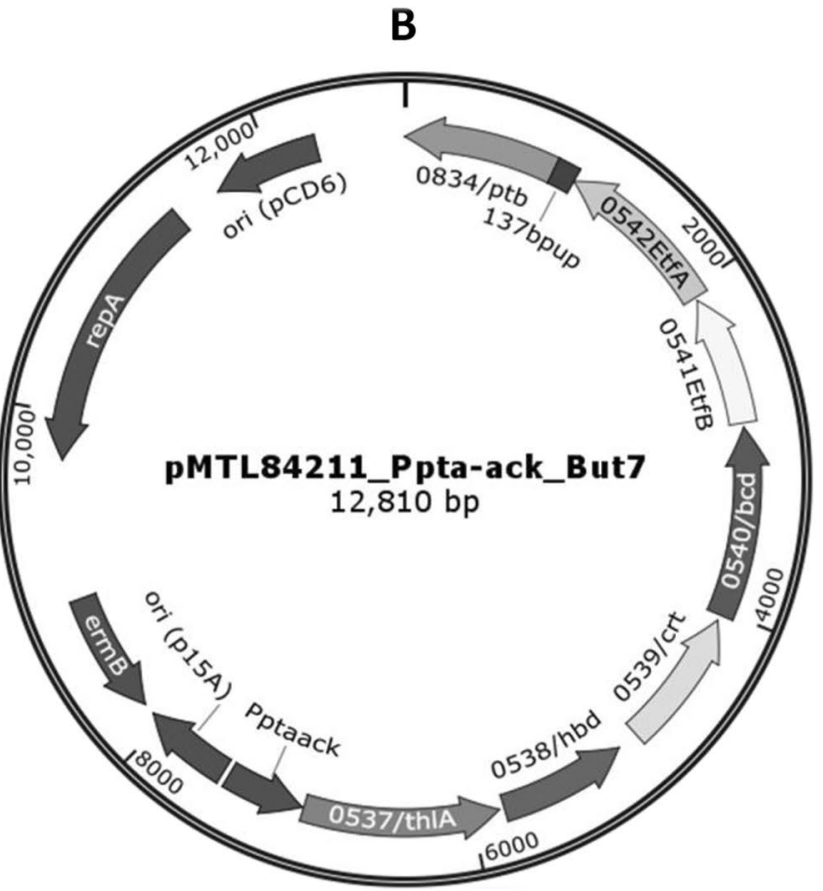

tyrylase; 137 bpup, upstream region of the ptb gene; pCD6, replicon of $C$. difficile plasmid $\mathrm{pD6}$; repA, gene encoding replicon protein; traJ, transfer function of the RP4 oriT region; ermB, the macrolidelincosamide-streptogramin B antibiotic resistance gene of plasmid pAMß1, Ppta-ack, the promoter of the $C$. ljungdahlii gene encoding phosphotransacetylase-acetate kinase gene 
A

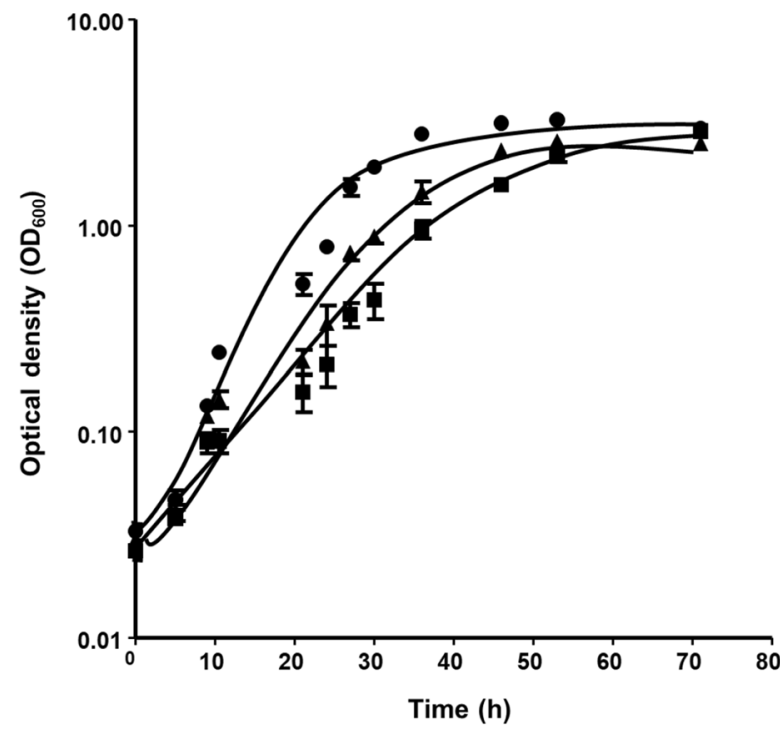

Fig. 2 Growth of recombinant A. woodii strains on $20 \mathrm{mM}$ fructose. A Pre-adapted recombinant $A$. woodii AW_ctrl (black circle), AW_ But6 (black square), and AW_But7 (black up-pointing triangle) were grown on $20 \mathrm{mM}$ fructose under a $\mathrm{N}_{2} / \mathrm{CO}_{2}[80 / 20 \%(\mathrm{v} / \mathrm{v})]$ atmosphere. The cultures were cultivated at $30^{\circ} \mathrm{C}$ and growth experiments

B

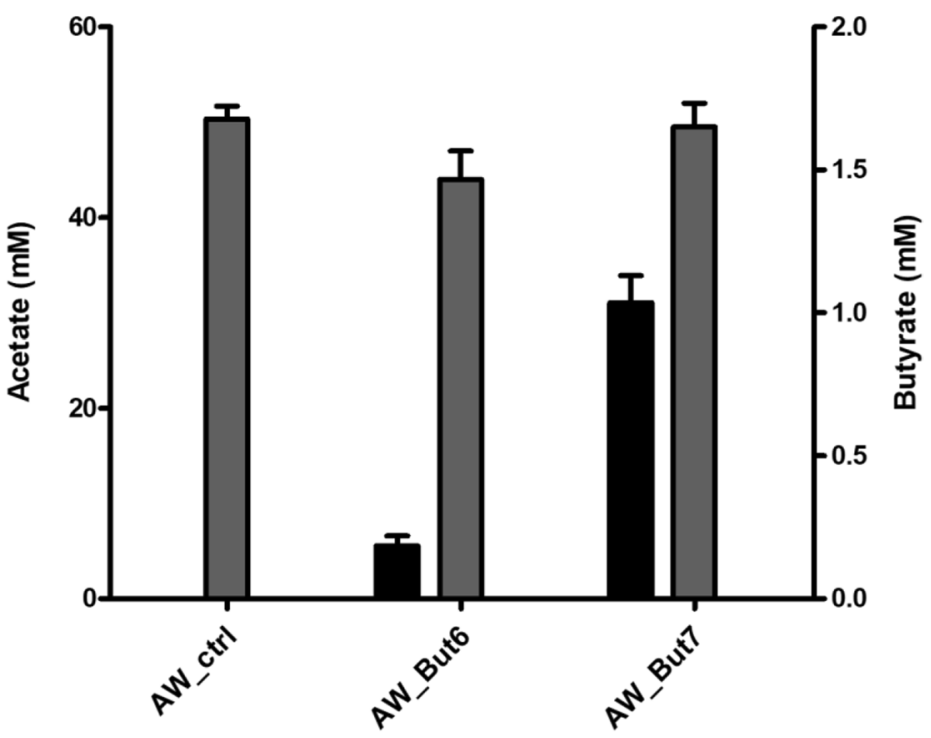

were performed in $50 \mathrm{ml}$ complex media. B Determination of acetate and butyrate at end of fructose fermentation; butyrate (black) and acetate (gray). Each data point indicates a mean \pm SEM; $n=2$ independent experiments
A

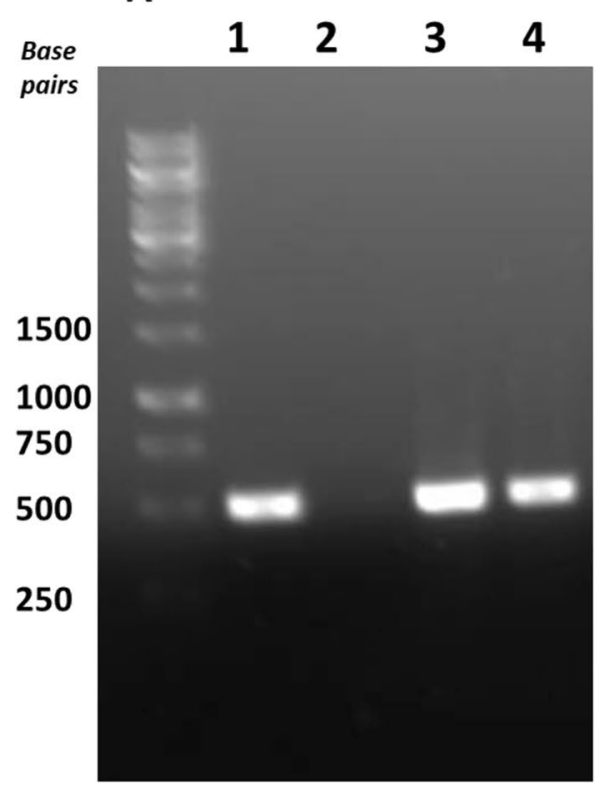

B

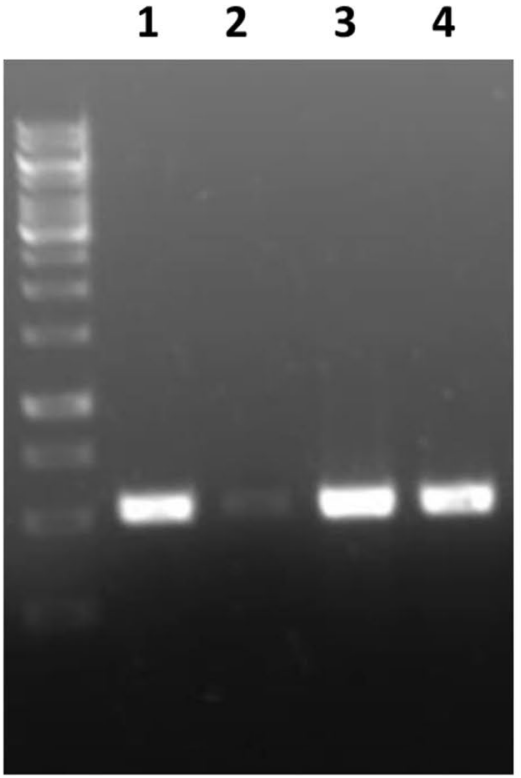

C

$\begin{array}{llll}1 & 2 & 3 & 4\end{array}$

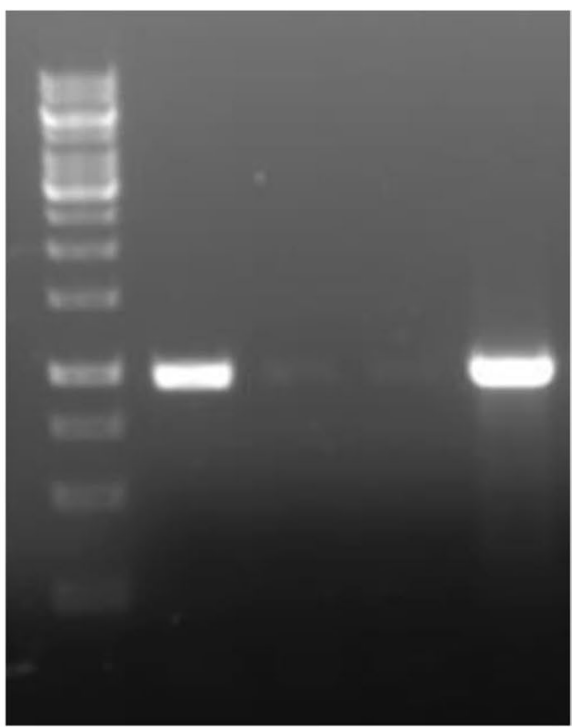

Fig. 3 Gene expression analysis of the synthetic butyrate pathway genes in Acetobacterium woodii. The transcript abundance of thiolase (A), hydroxybutyryl-CoA dehydrogenase (B), and phosphate butyryltransferase (C) were analyzed with semi-quantitive PCR (24 cycles) with cDNA as template. Chromosomal DNA from E. callanderi was used as control. Lane 1, E. callanderi chromosomal DNA; lane 2, cDNA from WT A. woodii; lane 3, cDNA from Aw_But6; lane 4, cDNA from Aw_But7 
$\mathrm{U} / \mathrm{mg}$, respectively. Acetate kinase activity was sevenfold higher in A. woodii $(3.1 \mathrm{U} / \mathrm{mg}$ ) and twice as high in E. callanderi $(1.38 \mathrm{U} / \mathrm{mg})$. Apparently, butyrate kinase activity is present in wild type A. woodii and E. callanderi.

\section{Butyrate production is carbon source dependent}

As shown above, butyrate was produced during growth on fructose as carbon source. A. woodii also grows lithotrophically on $\mathrm{H}_{2}+\mathrm{CO}_{2}$, but butyrate was not detected under these conditions in neither Aw_But6 nor Aw_But7 strains (data not shown). Like the wild type, Aw_But6 and Aw_But7 grew well on methanol, although the doubling time was increased $(24 \mathrm{~h})$ compared to the wild type $(16 \mathrm{~h})$. Methanol consumption was accompanied by the formation of acetate and a total of around $38 \mathrm{mM}$ of acetate was formed from $60 \mathrm{mM}$ methanol, corresponding to an acetate methanol ratio of 0.63 . Interestingly, parallel to the formation of acetate, butyrate production started in Aw_But7 strain at the mid exponential growth phase and reached a maximum of $0.25 \mathrm{mM}$ in the stationary phase (Fig. 4). Butyrate formation could not be detected in Aw_But6 strain.

\section{Butyrate production in non-growing cells}

Non-growing, resting cells have the advantage of not losing carbon to biosynthetic pathways. Therefore, we analyzed butyrate formation in resting cells. Cells grown on fructose and resuspended in buffer immediately started to produce acetate from fructose. Aw_ctrl strain, not carrying the butyrate synthetic genes, produced $37 \mathrm{mM}$ acetate from $17 \mathrm{mM}$ fructose. As expected, butyrate was not produced. Interestingly, in the recombinant strain, unlike in growing condition, fructose consumed to acetate formed was lower
(1:2.1) compared to growing cells $(\sim 1: 2.5)$. Aw_But6 produced less acetate $(36 \mathrm{mM})$, but when production started to reach the plateau, butyrate production started. Finally, $0.3 \mathrm{mM}$ butyrate was produced, similar to observed under growing conditions. In comparison to Aw_But6 strain, Aw_ But7 carrying $p t b$, in addition, produced similar amounts of acetate $(35 \mathrm{mM})$ but butyrate formation was increased drastically by $400 \%$ to a final concentration of $1.2 \mathrm{mM}$ (Fig. 5).

Cells of Aw_But7, grown on methanol and resuspended in buffer, also metabolized methanol but in contrast to growing cells, only acetate was produced and butyrate could not be detected. However, when carbon monoxide $(10 \% \mathrm{v} / \mathrm{v})$ was added to the headspace, acetate formation increased and concomitantly butyrate was produced up to a maximum concentration of $0.35 \mathrm{mM}$ (Fig. 6).

\section{Discussion and conclusion}

The global-interest in reducing levels of $\mathrm{CO}_{2}$ and increase carbon re-cycling led the scientific community to find several effective methods to fix $\mathrm{CO}_{2}$ artificially and also use microorganisms to convert $\mathrm{CO}_{2}$ into biochemicals. In recent years, a lot of success has been achieved where acetogens like Clostridium autoethanogenum (Köpke et al. 2014; Liew et al. 2016a, b; Heffernan et al. 2020), Clostridium ljungdahlii (Ueki et al. 2014), and Moorella thermoacetica (Kita et al. 2013) had been engineered with genes from other clostridia to utilize $\mathrm{H}_{2}+\mathrm{CO}_{2}$ or syngas to produce higher carbon chain biochemicals. In a proof-of-concept study, it was shown that $A$. woodii can produce acetone under autotrophic conditions when the thiolase, CoA transferase, and acetoacetate decarboxylase genes from Clostridium acetobutylicum were expressed (Hoffmeister et al. 2016). While
A

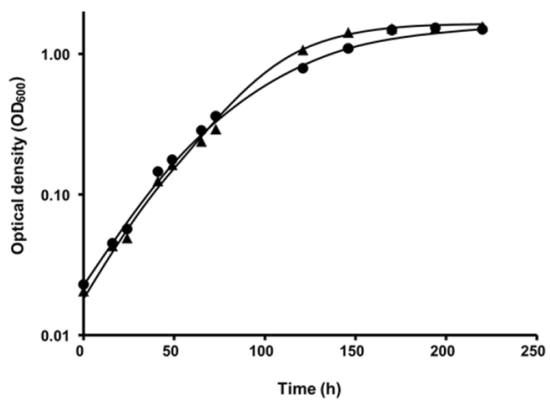

Fig. 4 Growth of recombinant A. woodii Aw_But6 and Aw_But7 on $60 \mathrm{mM}$ methanol and butyrate formation. A Methanol-adapted recombinant $A$. woodii Aw_But6 (black circle) and Aw But7 (black up-pointing triangle) were grown on $60 \mathrm{mM}$ methanol under a $\mathrm{N}_{2} /$ $\mathrm{CO}_{2}[80 / 20 \%(\mathrm{v} / \mathrm{v})]$ atmosphere. The cultures were cultivated at $30^{\circ} \mathrm{C}$ and growth experiments were performed in $500 \mathrm{ml}$ complex media

B

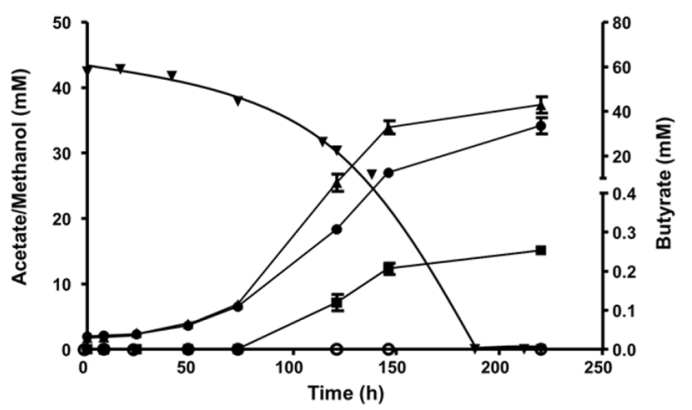

and optical density determined. B Concentrations of methanol (black down-pointing triangle), acetate (Aw_But6, black up-pointing triangle; Aw_But7, black circle), and butyrate (Aw_But6, open circle; Aw_But7, black square) were measured as described in "Materials and methods," and $\mathrm{OD}_{600}$ was determined photometrically. All data points are mean $\pm \mathrm{SEM} ; N=2$ independent experiments 
A

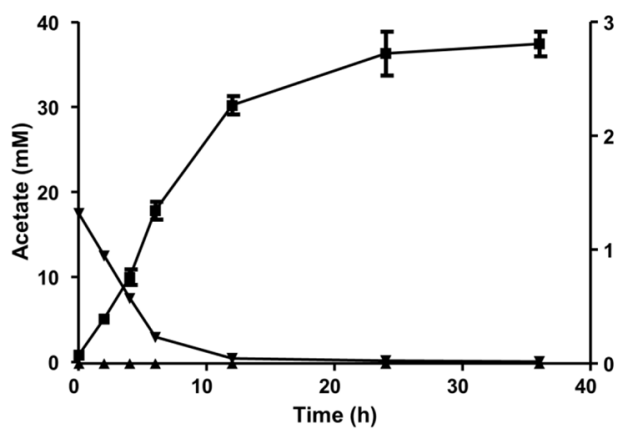

B

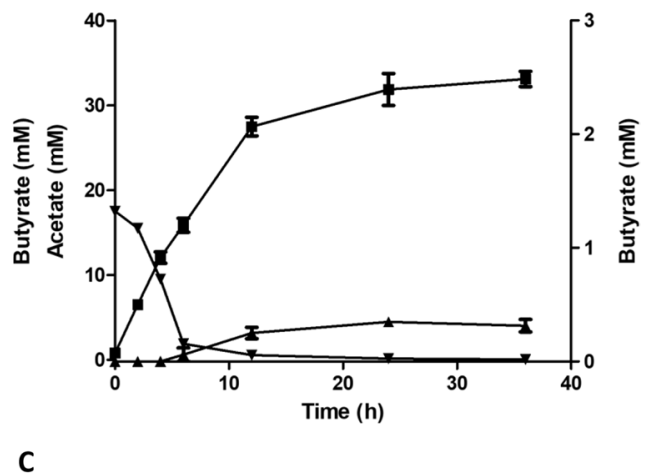

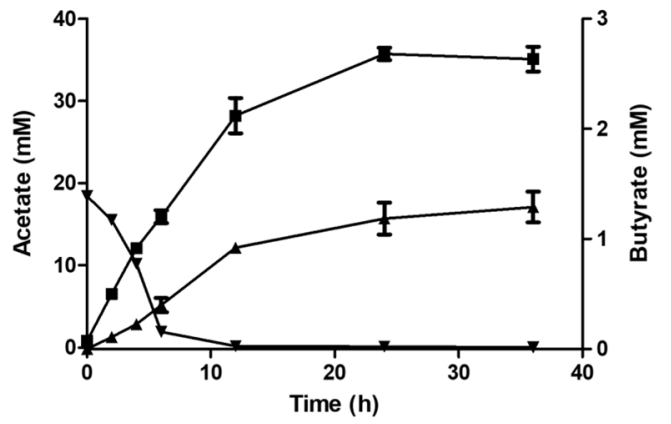

Fig. 5 Fructose uptake and conversion into acetate and butyrate by resting cells of recombinant $A$. woodii strains. Recombinant $A$. woodii strains were grown on $20 \mathrm{mM}$ fructose as described in "Materials and methods" and harvested in the late exponential growth phase. The cells were washed twice and resuspended to a final protein concentration of $1 \mathrm{mg} \mathrm{ml}^{-1}$ in $10 \mathrm{ml}$ imidazole buffer $(50 \mathrm{mM}$ imidazole, $20 \mathrm{mM} \mathrm{NaCl}, 20 \mathrm{mM} \mathrm{KCl}, 20 \mathrm{mM} \mathrm{MgSO}_{4}, 60 \mathrm{mM} \mathrm{KHCO}_{3}, \mathrm{pH} 7.0$ ) in 115-ml serum bottles under a $\mathrm{N}_{2} / \mathrm{CO}_{2}$ atmosphere (80:20 [v/v]). A total of $20 \mathrm{mM}$ fructose was given to cell suspension of Aw_ctrl (A), Aw_But6 (B), and Aw_But7 (C). Samples were drawn at different time points for quantification of fructose (black down-pointing triangle), acetate (black square), and butyrate (black up-pointing triangle). All data points are mean \pm SEM; $N=2$ independent experiments

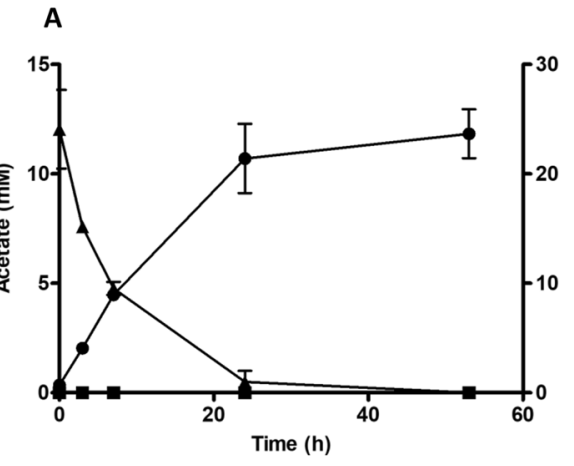

Fig. 6 Methanol uptake and conversion into acetate and butyrate by resting cells of recombinant $A$. woodii. A. woodii Aw_But7 was grown on $60 \mathrm{mM}$ methanol as described in the "Materials and methods" section and harvested in the late exponential growth phase. The cells were washed twice and resuspended to a final protein concentration of $0.8 \mathrm{mg} \mathrm{ml}^{-1}$ in $10 \mathrm{ml}$ imidazole buffer $(50 \mathrm{mM}$ imidazole,

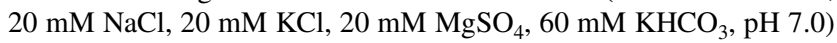

B

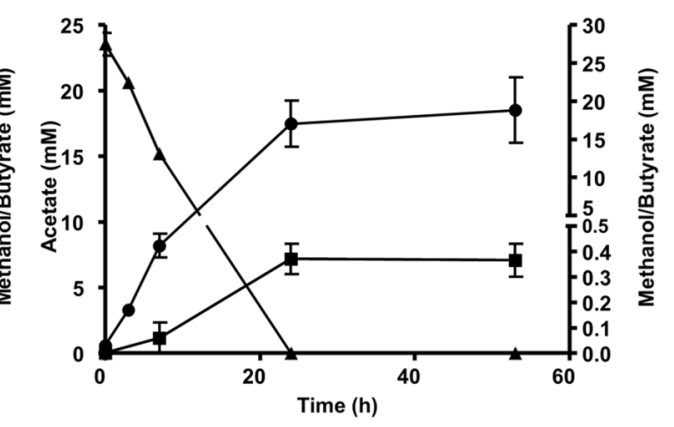

in $115-\mathrm{ml}$ serum bottles. The experiments were performed under a $\mathrm{N}_{2} / \mathrm{CO}_{2}$ atmosphere (80:20) (A) additional 10\% CO (B). Samples were drawn at different time points for quantification of acetate (black circle), butyrate (black square), and methanol (black up-pointing triangle) by gas chromatography. All data points are mean $\pm \mathrm{SEM} ; N=2$ independent experiments 
most biochemical production pathways are energy invasive, in a very recent study, recombinant $A$. woodii (Beck et al. 2020) was shown to conserve additional energy when the arginine deiminase pathway from $C$. autoethanogenum was heterologusly produced in $A$. woodii. The production of longer carbon-chain compounds in A. woodii would also require additional supply of energy and indeed this approach will find its merit.

Here in this study, we rather ask a very simple question. Can we can transfer metabolic pathways within related acetogens and induce them to produce a chemical that the other does not produce? It has been reported before that under certain circumstances, E. callanderi KIST612 naturally produces butyrate along with acetate as sole end products (Jeong et al. 2015; Dietrich et al. 2021; Litty and Müller 2021). The results presented here clearly demonstrate that transferring the butyrate formation pathway in a related acetogen like $A$. woodii that does not produce butyrate naturally leads to production of butyrate in the recombinant $A$. woodii strains. However, the maximal amount of butyrate produced during growth on $60 \mathrm{mM}$ methanol was rather low $(0.25 \mathrm{mM})$ in comparison to E. callanderi KIST612 (3.7 mM butyrate on $20 \mathrm{mM}$ methanol). While the butyrate formation pathway requires the eight proteins thiolase, hydroxybutyryl-CoA dehydrogenase, crotonase, butyryl-CoA dehydrogenase/ electron transferring flavoprotein complex, phosphotransbutyrylase, and butyrate kinase, introduction of only seven of the protein encoding genes into $A$. woodii led to continued formation of butyrate from both $\mathrm{C} 6$ and $\mathrm{C} 1$ compounds. Though the terminal gene of the butyrate pathway encoding for a butyrate kinase was missing, it is likely that the highly active acetate kinase (ack, Awo_c21260) synthesizes butyrate from butyryl-phosphate in recombinant $A$. woodii (Eden und Fuchs 1983; Schuchmann and Müller 2014). Indeed, cell-free extract of $A$. woodii showed butyrate kinase activity. Whether this is done by the acetate kinase or by an unknown butyrate kinase remains to be established. The same is true for E. callanderi. It should also be noted that the acetate kinase from Methanosarcina thermophila, which is $60 \%$ identical to the acetate kinase from $A$. woodii, can utilize butyrate, although with a 50-fold higher $\mathrm{k}_{\mathrm{m}}$ value (Ingram-Smith et al. 2005).

Also, we could show that recombinant $A$. woodii could produce a four-carbon product $(\mathrm{C} 4)$ from a $\mathrm{C} 1$ compound like methanol. The metabolism of methanol in recombinant A. woodii likely involves the methanol-specific methyltransferase system (Kremp et al. 2018; Kremp and Müller 2021) to generate methyl-THF which further condenses with an incoming $\mathrm{CO}$ using $\mathrm{CODH} / \mathrm{ACS}$ enzyme to generate the central metabolic intermediate, acetyl-CoA. In recombinant strains, acetyl-CoA is further metabolized downstream to produce acetate or butyrate and conserve energy. The anaerobic utilization of methanol via the WLP provides NADH but needs an input of reduced ferredoxin for reduction of
$\mathrm{CO}_{2}$ to $\mathrm{CO}$ (Fig. 7A). Reduced ferredoxin is generated from NADH by reverse electron transport catalyzed by the Rnf complex, energized by ATP hydrolysis (Kremp and Müller 2021). However, the production of butyrate from methanol requires NADH (Song et al. 2017) by hydroxybutyryl-CoA dehydrogenase and the electron bifurcating Bcd/EtfAB complex (Buckel und Thauer 2013; Jeong et al. 2015; Katsyv and Müller 2020) (Fig. 7A), which are generated by methanol oxidation. Importantly, the electron bifurcating butyryl-CoA dehydrogenase provides reduced ferredoxin, the fuel for electron transport phosphorylation thus increasing the ATP yield. In theory, from 5 methanol and $1 \mathrm{CO}_{2}$, 1.5 butyrate could be produced leading to an ATP yield of $0.64 \mathrm{~mol} \mathrm{ATP} / \mathrm{mol}$ methanol consumed according to Eq. 2 (Fig. 7A):

$$
\begin{aligned}
& 5 \mathrm{CH}_{3} \mathrm{OH}+1 \mathrm{CO}_{2}+3.2 \mathrm{ADP}+3.2 \mathrm{Pi} \rightarrow \\
& 1.5 \mathrm{CH}_{3} \mathrm{C}_{2} \mathrm{H}_{4} \mathrm{COOH}+4 \mathrm{H}_{2} \mathrm{O}+3.2 \mathrm{ATP}
\end{aligned}
$$

In recombinant strains, the effective utilization of NADH is supposed to shift the acetate:butyrate ratio in favor of butyrate when cells are grown on methanol $+\mathrm{CO}_{2}$. This was true for Aw_But7 strain during growth on methanol $(60 \mathrm{mM})$. However, the recovery of carbon in form of butyrate was relatively low in comparison to acetate, which is attributed either by the missing butyrate kinase or electron imbalance. In such a scenario, during cell suspension assays, with reduced electron pressure in form of lower concentration of methanol $(20 \mathrm{mM})$, Aw_But7 strain did not synthesize butyrate.

Our results show that this electron imbalance could be partially surpassed by introduction of electron rich $\mathrm{CO}$ gas into the gaseous phase which significantly enhanced butyrate formation in the recombinant strain. In theory, butyrogenesis from methanol $+\mathrm{CO}$ is simple and involves condensation of 2 methanol with $2 \mathrm{CO}$ leading to the formation of 1 butyrate. Also, owing to the reduced ferredoxin generated by $\mathrm{CO}$ oxidation, in this modular branch, an increase in the energy efficiency by almost $140 \%$ can be obtained with an ATP yield of $1.55 \mathrm{~mol} \mathrm{ATP} / \mathrm{mol}$ methanol consumed according to Eq. 3 (Fig. 7B):

$$
\begin{aligned}
& 2 \mathrm{CH}_{3} \mathrm{OH}+5 \mathrm{CO}+3.1 \mathrm{ADP}+3.1 \mathrm{Pi} \rightarrow \\
& 1 \mathrm{CH}_{3} \mathrm{C}_{2} \mathrm{H}_{4} \mathrm{COOH}+3 \mathrm{CO}_{2}+1 \mathrm{H}_{2}+3.1 \mathrm{ATP}
\end{aligned}
$$

However, in this case, addition of $\mathrm{CO}$ also increased acetate formation and this stresses the necessity of tailoring the pathway by specific genetic deletion to redirect the carbon flux towards butyrate instead of acetate. One such approach would be to delete the acetate kinase or phosphotransacetylase gene and introduce a clostridial butyrate kinase to complete the butyrate synthetic pathway. Indeed, it was reported that deletion of pta in C. ljungdahlii led to a decrease in acetate production by $>80 \%$ and improved ethanol formation 
A

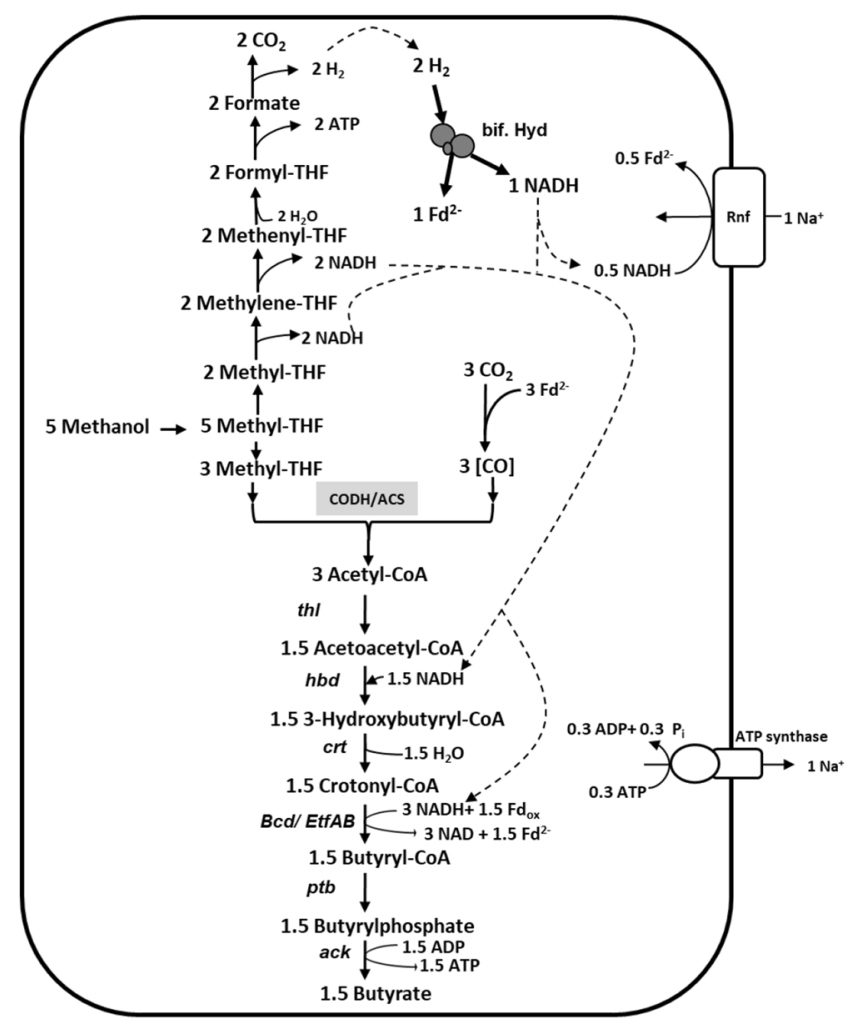

Fig. 7 Model of butyrate formation from methanol (A) or metha$\mathrm{nol}+\mathrm{CO}(\mathbf{B})$. Carbon and probable electron flow in methanol metabolism of butyrate producing recombinant $A$. woodii; for explanation, see text. The stoichiometry of the ATPase is $3.3 \mathrm{Na}^{+} /$ATP (Matthies et al. 2014), and the stoichiometry of the Rnf complex is assumed

via aldehyde ferredoxin oxidoreductase (AOR) (Lo et al. 2020). We could imagine that a similar deletion in A. woodii would lead to an accumulation of acetyl-CoA and in the presence of a recombinant butyrate pathway, the carbon flux would also be pushed towards the ATP generating butyrate synthesis. Finally, this study shows that $A$. woodii can be made to produce butyrate from methanol or methanol $+\mathrm{CO}$ which makes methanol a promising feedstock for an alternative bioeconomy using acetogens as biocatalyst.

\section{Materials and methods}

\section{Cultivation of A. woodii and E. callanderi KIST612}

A. woodii DSMZ 1030 and transformants were cultivated under strict anoxic conditions at $30^{\circ} \mathrm{C}$ in carbonate buffered complex medium. The medium was prepared as described previously (Heise et al. 1989). Fructose (20 mM), methanol $(60 \mathrm{mM})$, or $\mathrm{H}_{2}+\mathrm{CO}_{2}(80: 20[\mathrm{v} / \mathrm{v}])$ served as a sole carbon and energy source for butyrate production studies. Transformed A. woodii cells harboring butyrate pathway
B

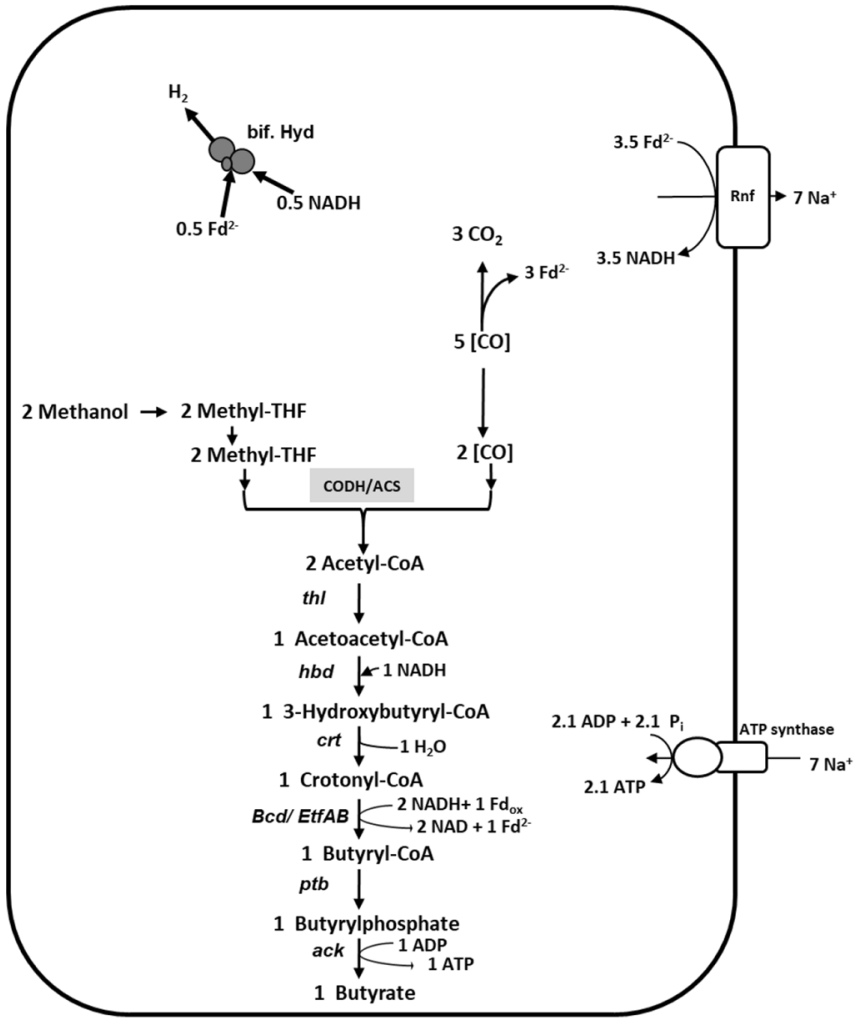

to be $2 \mathrm{Na}^{+} / 2$ electrons. Abbreviations: CODH/ACS, CO dehydrogenase/acetyl-CoA synthase complex; bif. Hyd, electron bifurcating hydrogenase; Rnf, Rnf complex; thlA, thiolase; $h b d$, hydroxybutyrylCoA dehydrogenase; $c r t$, crotonase; $b c d / e t f B A$, bifurcating butyrylCoA dehydrogenase complex; $p t b$, phosphotransbutyrylase

genes were first selected on Heise media containing $20 \mathrm{mM}$ fructose and $15 \mu \mathrm{g} / \mathrm{ml}$ erythromycin. E. callanderi KIST612 was cultivated at $37^{\circ} \mathrm{C}$ in anoxic carbonate-buffered basal medium (CBBM) (Chang et al. 1999) with glucose under a $\mathrm{N}_{2} / \mathrm{CO}_{2}(80 / 20 \%[\mathrm{v} / \mathrm{v}])$ atmosphere. Growth was followed by measuring the optical density at $600 \mathrm{~nm}$. All growth experiments were performed in $115-\mathrm{ml}$ serum flasks containing $50 \mathrm{ml}$ of media.

\section{Construction of plasmids for butyrate production}

For the construction of a synthetic pathway, the genes necessary for synthesis of butyrate in E. callanderi KIST612 were selected and amplified by PCR. The genes clustered in the butyrate operon, ELI_0537 - ELI_0542, consisting of thiolase (thlA), 3-hydroxybutyryl-CoA dehydrogenase ( $h b d$ ), crotonase $(c r t)$, butyryl-CoA dehydrogenase $(b c d)$, and two subunits of electron transferring flavoprotein $(E t f A / B)$ were amplified and subcloned into pMTL84211 backbone (Purdy et al. 2002) together (upstream) with PCR-amplified $\mathrm{P}_{\text {pta-ack }}$ promoter from $C$. ljungdahlii. The resulting plasmid was called pMTL84211Ack_NP_But6. Furthermore, the 
phosphobutyryl transferase (ptb, ELI_0834) with its 137 bp upstream region was also amplified by PCR and subcloned into the pMTL84211_6kb plasmid, downstream of etfA (ELI_0542). The resulting plasmid had 7 genes (thl, $h b d$, $c r t, b c d / E t f A B$, and $p t b)$ of the butyrate synthetic pathway and was called pMTL84211Ack_NP_But7. A control plasmid was also created by fusing PCR-amplified $\mathrm{P}_{\text {pta-ack }}$ promoter into the pMTL84211 vector with no other genes. All subcloning procedures were performed using fusion cloning strategy using NEBuilder HiFi DNA Assembly Kit (New England Biolabs, USA). Transformation was performed according to an earlier described procedure (Westphal et al. 40). In both the plasmids, the butyrate synthetic genes were under the direct control of the strong $\mathrm{P}_{\text {pta-ack }}$ promoter. The plasmids were used to electro-transform $A$. woodii WT cells to generate Aw_ctrl (control), Aw_But6 (6 gene variant), and Aw_But7 (7 gene variant) strains, respectively. The transformants were grown in a volume of $5 \mathrm{ml}$ of carbonate-buffered complex medium (Heise et al. 1989) containing $20 \mathrm{mM}$ fructose and $15 \mu \mathrm{g} / \mathrm{ml}$ erythromycin.

\section{Semi-quantitative PCR for gene expression analysis}

To analyze transcript levels of butyrate synthetic genes in A. woodii, RNA was prepared from recombinant A. woodii strains (Aw_But6 or Aw_But7) grown on fructose or $\mathrm{H}_{2}+\mathrm{CO}_{2}$ to mid-exponential growth phase as described earlier (Chowdhury et al. 2020). A total of $1 \mu \mathrm{g}$ of RNA from each sample was converted into cDNA by using M-MLV Reverse Transcriptase according to the manufacturer's protocol (Promega, Mannheim, Germany). Transcript levels of representative genes of the butyrate operon ( $t h l A$ and $h b d$ ) and $p t b$ were analyzed using gene-specific primers (see Supplementary, Table 1). PCRs were performed using Phusion DNA polymerase (NEB, USA) with $10 \mathrm{ng}$ cDNA as template and $500 \mathrm{nM}$ of gene-specific primers in a final reaction volume of $25 \mu$ l. Confirmation of gene expression on different substrates was done by analyzing PCR products on an agarose gel.

\section{Preparation of cell suspensions and analysis}

For cell suspension analysis, recombinant $A$. woodii strains were adapted on either fructose, methanol or $\mathrm{H}_{2}+\mathrm{CO}_{2}$ and cells were grown in 500/1000 ml volumes to mid-exponential growth phase. Cells were harvested by centrifugation $(10,000 \times g ; 10 \mathrm{~min})$ and washed two times with imidazole buffer A ( $50 \mathrm{mM}$ imidazole- $\mathrm{HCl}, 20 \mathrm{mM} \mathrm{MgSO}_{4}, 20 \mathrm{mM}$ $\mathrm{KCl}, 2 \mathrm{mM}$ dithioerythritol (DTE), $1 \mathrm{mg} \bullet \mathrm{l}^{-1}$ resazurin, $\mathrm{pH}$ 7.0) under strictly anoxic conditions in an anaerobic chamber (Coy Laboratory Products, Grass Lake, MI) filled with 95-98\% $\mathrm{N}_{2}$ and 2-5\% $\mathrm{H}_{2}$ as described previously (Heise et al. 1992). Cells were resuspended in 115-ml glass bottles in resuspension buffer (imidazole buffer supplemented with $20 \mathrm{mM} \mathrm{NaCl}$ and $60 \mathrm{mM} \mathrm{KHCO}_{3}, \mathrm{pH}$ 7.2) either under a $\mathrm{N}_{2} / \mathrm{CO}_{2}$ or $\mathrm{H}_{2} / \mathrm{CO}_{2}$ atmosphere (80:20 [v/v]).

For determination of the conversion of methanol in cell suspension experiments, $10 \% \mathrm{CO}$ was added to the $\mathrm{N}_{2} / \mathrm{CO}_{2}$ headspace with no overpressure. For acetogenesis from $\mathrm{H}_{2}+\mathrm{CO}_{2}$ by recombinant $A$. woodii, a cell concentration corresponding to $1 \mathrm{mg}$ total cell protein per $\mathrm{ml}$ and a gas atmosphere of $\mathrm{H}_{2}+\mathrm{CO}_{2}(80: 20[\mathrm{v} / \mathrm{v}])$ at 1 bar overpressure were used. The suspensions were incubated at $30^{\circ} \mathrm{C}$ in a shaking water bath and substrate/product analyses were done as earlier mentioned. Substrate/product analyses were done from $500 \mu \mathrm{l}$ samples withdrawn with a syringe at different time points. The concentrations of acetate or butyrate were determined by gas chromatography as described previously (Litty and Müller 2021). The peak areas were proportional to the concentration of each substance and calibrated with standard curves. A total of $5 \mathrm{mM}$ isopropanol was used as the internal standard for all measurements.

\section{Determination of acetate and butyrate kinase activities}

A. woodii and E. callanderi were grown on $20 \mathrm{mM}$ fructose to mid-exponential growth phase, harvested, and washed twice in buffer A (50 mM Tris/ $\mathrm{HCl}, 5 \mathrm{mM} \mathrm{MgCl}$, $\mathrm{pH} 7.5$ ). Cells were broken in a French pressure cell at $110 \mathrm{MPa}$ and the resulting cell-free extract was freed of cells by low speed centrifugation ( 8 min, 8000 Upm; JA 25.50 rotor, Beckmann Coulter, Krefeld, Germany). Acetate kinase was measured by an NADH-coupled enzyme assay as described previously (Lindley et al. 1987). The assay mixture contained Tris/HCl (pH 7.5), 4 mM ATP, 1.7 mM PEP, 0.3 mM NADH, pyruvate kinase $(1 \mathrm{U})$, lactate dehydrogenase $(1 \mathrm{U})$, and $750 \mathrm{mM}$ of acetate. The reactions were started with acetate after addition of acetate kinase-containing samples. NADH oxidation was followed at $340 \mathrm{~nm}$. The same assay was used to determine butyrate kinase activity by omitting acetate and adding butyrate $(750 \mathrm{mM})$ instead.

Supplementary Information The online version contains supplementary material available at https://doi.org/10.1007/s10123-022-00234-z.

Author contribution NPC and VM designed the research. NPC and DL performed the experiments, analyzed the data, and prepared the figures. NPC, DL, and VM wrote the manuscript.

Funding Open Access funding enabled and organized by Projekt DEAL. The research was funded by an Advanced Grant of the European Research Council under the European Union's Horizon 2020 Research and Innovation Program (grant agreement no. 741791).

Data availability Not applicable.

Code availability Not applicable. 


\section{Declarations}

Conflict of interest The authors declare no competing interests.

Open Access This article is licensed under a Creative Commons Attribution 4.0 International License, which permits use, sharing, adaptation, distribution and reproduction in any medium or format, as long as you give appropriate credit to the original author(s) and the source, provide a link to the Creative Commons licence, and indicate if changes were made. The images or other third party material in this article are included in the article's Creative Commons licence, unless indicated otherwise in a credit line to the material. If material is not included in the article's Creative Commons licence and your intended use is not permitted by statutory regulation or exceeds the permitted use, you will need to obtain permission directly from the copyright holder. To view a copy of this licence, visit http://creativecommons.org/licenses/by/4.0/.

\section{References}

Beck MH, Flaiz M, Bengelsdorf FR, Dürre P (2020) Induced heterologous expression of the arginine deiminase pathway promotes growth advantages in the strict anaerobe Acetobacterium woodii. Appl Microbiol Biotechnol 104:687-699

Chang IS, Kim BH, Kim DH, Lovitt RW, Sung HC (1999) Formulation of defined media for carbon monoxide fermentation by Eubacterium limosum KIST612 and the growth characteristics of the bacterium. J Biosci Bioeng 88:682-685

Chang IS, Kim DH, Kim BH, Shin PK, Yoon JH, Lee JS, Park YH (1997) Isolation and identification of carbon monoxide utilizing anaerobe, Eubacterium limosum KIST612. Kor J Appl Microbiol Biotechnol 25:1-8

Chowdhury NP, Alberti L, Linder M, Müller V (2020) Exploring bacterial microcompartments in the acetogenic bacterium Acetobacterium woodii. Front. Microbiol 11:593467

Cotton CA, Claassens NJ, Benito-Vaquerizo S, Bar-Even A (2019) Renewable methanol and formate as microbial feedstocks. Curr Opin Biotechnol 62:168-180

Diender M, Stams AJ, Sousa DZ (2016) Production of medium-chain fatty acids and higher alcohols by a synthetic co-culture grown on carbon monoxide or syngas. Biotechnol Biofuels 9:82

Buckel W, Thauer RK (2013) Energy conservation via electron bifurcating ferredoxin reduction and proton/ $\mathrm{Na}^{+}$translocating ferredoxin oxidation. Biochim Biophys Acta 1827:94-113

Dietrich HM, Kremp F, Öppinger C, Ribaric L, Müller V (2021) Biochemistry of methanol-dependent acetogenesis in Eubacterium callanderi KIST612. Environ Microbiol 23:4505-4517

Drake HL (1994) Acetogenesis, acetogenic bacteria, and the acetylCoA "Wood/Ljungdahl" pathway: past and current perspectives. In: Drake HL (ed) Acetogenesis. Springer, US, New York, pp 3-60

Drake HL, Gößner AS, Daniel SL (2008) Old acetogens, new light. Ann N Y Acad Sci 1125:100-128

Drake HL, Daniel S, Küsel K, Matthies C, Kuhner C, Braus-Strohmeyer S (1997) Acetogenic bacteria: what are the in situ consequences of their diverse metabolic diversities? BioFactors 1:13-24

Eden G, Fuchs G (1983) Autotrophic $\mathrm{CO}_{2}$ fixation in Acetobacterium woodii. II. Demonstration of enzymes involved. Arch Microbiol 135:68-73

Heap JT, Pennington OJ, Cartman ST, Carter GP, Minton NP (2007) The ClosTron: a universal gene knock-out system for the genus Clostridium. J Microbiol Methods 70:452-464

Heffernan JK, Valgepea K, de Souza Pinto Lemgruber R, Casini I, Plan M, Tappel R et al (2020) Enhancing $\mathrm{CO}_{2}$-valorization using
Clostridium autoethanogenum for sustainable fuel and chemicals production. Front Bioeng Biotechnol 8:204

Heise R, Müller V, Gottschalk G (1989) Sodium dependence of acetate formation by the acetogenic bacterium Acetobacterium woodii. $\mathrm{J}$ Bacteriol 171:5473-5478

Heise R, Müller V, Gottschalk G (1992) Presence of a sodium-translocating ATPase in membrane vesicles of the homoacetogenic bacterium Acetobacterium woodii. Eur J Biochem 206:553-557

Hoffmeister S, Gerdom M, Bengelsdorf FR, Linder S, Fluchter S, Oztürk H et al (2016) Acetone production with metabolically engineered strains of Acetobacterium woodii. Metab Eng 36:37-47

Ingram-Smith C, Gorrell A, Lawrence SH, Iyer P, Smith K, Ferry JG (2005) Characterization of the acetate binding pocket in the Methanosarcina thermophila acetate kinase. J Bacteriol 187:2386-2394

Jeong J, Bertsch J, Hess V, Choi S, Choi IG, Chang IS, Müller V (2015) Energy conservation model based on genomic and experimental analyses of a carbon monoxide-utilizing, butyrate-forming acetogen, Eubacterium limosum KIST612. Appl Environ Microbiol 81:4782-4790

Katsyv A, Müller V (2020) Overcoming energetic barriers in acetogenic $\mathrm{C} 1$ conversion. Front Bioeng Biotechnol 8:621166

Kita A, Iwasaki Y, Sakai S, Okuto S, Takaoka K, Suzuki T et al (2013) Development of genetic transformation and heterologous expression system in carboxydotrophic thermophilic acetogen Moorella thermoacetica. J Biosci Bioeng 115:347-352

Köpke M, Gerth ML, Maddock DJ, Müller AP, Liew F, Simpson SD, Patrick WM (2014) Reconstruction of an acetogenic 2,3-butanediol pathway involving a novel NADPH-dependent primarysecondary alcohol dehydrogenase. Appl Environ Microbiol 80:3394-3403

Kremp F, Poehlein A, Daniel R, Müller V (2018) Methanol metabolism in the acetogenic bacterium Acetobacterium woodii. Environ Microbiol 20:4369-4384

Kremp F, Müller V (2021) Methanol and methyl group conversion in acetogenic bacteria: biochemistry, physiology and application. FEMS Microbiol Rev 45: fuaa040

Liew F, Martin ME, Tappel RC, Heijstra BD, Mihalcea C, Köpke M (2016a) Gas fermentation-a flexible platform for commercial scale production of low-carbon-fuels and chemicals from waste and renewable feedstocks. Front Microbiol 7:694

Liew F, Henstra AM, Winzer K, Köpke M, Simpson SD, Minton NP (2016) Insights into $\mathrm{CO}_{2}$ fixation pathway of Clostridium autoethanogenum by targeted mutagenesis. mBio 7:e00427-00416

Lindley ND, Loubiere P, Pacaud D, Mariotto C, Goma G (1987) Novel products of the acidogenic fermentation of methanol during growth of Eubacterium limosum in the presence of high concentrations of organic acids. J Gen Microbiol 133:3557-3563

Liou JS, Balkwill DL, Drake GR, Tanner RS (2005) Clostridium carboxidivorans sp. nov., a solvent-producing clostridium isolated from an agricultural settling lagoon, and reclassification of the acetogen Clostridium scatologenes strain SL1 as Clostridium drakei sp. nov. Int J Syst Evol Microbiol 55:2085-2091

Litty D, Müller V (2021) Butyrate production in the acetogen Eubacterium limosum is dependent on the carbon and energy source. Microb Biotechnol 14:2686-2692

Lo J, Humphreys JR, Jack J, Urban C, Magnusson L, Xiong W, Gu Y, Ren ZJ, Maness, PC (2020) The metabolism of Clostridium ljungdahlii in phosphotransacetylase negative strains and development of an ethanologenic strain. Front bioeng biotechnol 8:560726

Matthies D, Zhou W, Klyszejko A, Anselmi C, Yildiz Ö, Brandt K, Müller V, Faraldo-Gómez JD, Meier D (2014) High-resolution structure and mechanism of an F/V-hybrid rotor ring in a $\mathrm{Na}^{+}$-coupled ATP synthase. Nat Comun 5:5286

Müller V (2003) Energy conservation in acetogenic bacteria. Appl Environ Microbiol 69:6345-6353 
Purdy D, O'Keeffe TA, Elmore M, Herbert M, McLeod A, BokoriBrown $M$ et al (2002) Conjugative transfer of clostridial shuttle vectors from Escherichia coli to Clostridium difficile through circumvention of the restriction barrier. Mol Microbiol 46:439-452

Satanowski A, Bar-Even A (2020) A one-carbon path for fixing $\mathrm{CO}_{2}: \mathrm{C}_{1}$ compounds, produced by chemical catalysis and upgraded via microbial fermentation, could become key intermediates in the valorization of $\mathrm{CO}_{2}$ into commodity chemicals. EMBO Rep 21:e50273

Schuchmann K, Müller V (2014) Autotrophy at the thermodynamic limit of life: a model for energy conservation in acetogenic bacteria. Nat Rev Microbiol 12:809-821

Schuchmann K, Müller V (2016) Energetics and application of heterotrophy in acetogenic bacteria. Appl Environ Microbiol 82:4056-4069
Song Y, Shin J, Jeong Y, Jin S, Lee JK, Kim DR et al (2017) Determination of the genome and primary transcriptome of syngas fermenting Eubacterium limosum ATCC 8486. Sci Rep 7:13694

Ueki T, Nevin KP, Woodard TL, Lovley DR (2014) Converting carbon dioxide to butyrate with an engineered strain of Clostridium ljungdahlii. Mbio 5:e01636-e1614

van den Abbeele P, Belzer C, Goossens M, Kleerebezem M, de Vos WM, Thas O et al (2013) Butyrate-producing Clostridium cluster XIVa species specifically colonize mucins in an in vitro gut model. ISME J 7:949-961

Westphal L, Wiechmann A, Baker J, Minton NP, Müller V (2018) The Rnf complex is an energy coupled transhydrogenase essential to reversibly link cellular NADH and ferredoxin pools in the acetogen Acetobacterium woodii. J Bacteriol 200:e0357-e318

Publisher's note Springer Nature remains neutral with regard to jurisdictional claims in published maps and institutional affiliations. 